\title{
COMPARATIVE EFFICACY OF LOCAL ISOLATES OF ENTOMOPATHOGENIC BACTERIA AND COMMERCIAL PRODUCT OF Bacillus thurengeinsis BERL. (AGERIN) ON COTTON BOLLWORMS. \\ Abd El-Kareim, A. I. ${ }^{1}$; M. E. El-Naggar² and Salma K. R. Mohamed ${ }^{2}$ ${ }^{1}$ Economic Entomology Dept., Fac. of Agric., Mansoura Univ., Egypt. ${ }^{2}$ Agric. Res. Center (ARC), Ministry of Agriculture, Egypt.
}

\begin{abstract}
The present study was conducted Aga district El-Dakhlia governorate, throughout 2006 and 2007cotton seasons.

During the course of this study, three strains (I, II and III strains) of entomopathogenic bacteria belonging to Bacillus thurengeinsis Berl. were isolated from the pink (PBW), Pectinophora. gossypiella (Saund.), spiny (SBW), Earias. insulana (Boisd.) and American (ABW), Helicoverpa. armigera (Hub.) bollworms. In addition, two bacterial pathogens namely, (Streptomyces avermecti and Micrococcus sp.) were isolated from the previously bollworm larvae.

The pathogenicity of each pathogen suspension was evaluated under laboratory conditions against the fourth larval instars of ABW, SBW and PBW. Statistical analysis indicated that $B$. thurigiensis strains (especially strain I) induced the highest pathogenicity to ABW, SBW and PBW larvae, while $S$. avermecti ranked second in the order of activity. Micrococcus sp. induced the lowest pathogenicity.

The efficiency of the local strain (I) of $B$. thurigiensis in comparison with the commercial isolate (Agerin) was evaluated under field conditions. The In the first season (2006), the mean reduction percentages of infestation caused by PBW, SBW and $A B W$ were $61.8,65.5$ and $74.2 \%$ in cotton fields treated with the local isolate $(B$. thurengeinsis strain I), while, the mean reduction percentages of infestation in Agerin treatment were $48.5,56.9$ and $66.1 \%$, respectively in comparison with control. In the second season (2007), the mean reduction percentages of infestation were $60.4,55.6$ $\& 63.5 \%$ for local isolate of $B$. thurigiensis and $47.7,46.0$ \& $52.4 \%$ for Agerin treatment, respectively.
\end{abstract}

\section{INTRODUCTION}

Cotton bollworms (American bollworm, Helicoverpa armigera (Hub.), spiny bollworm, Earias insulana (Boisd.) and pink bollworm, Pectinophora gossypiella (Saund.)) are important pests of cotton. Bollworms mainly feed on fruiting parts of cotton resulting in considerable quality and quantity losses [Ahmad, 1980] and 20-60\% damage and a decrease in market value of fiber [Verma, 1999].

$H$. armigera tunnels into small squares, terminal buds [Bohmfalk et al., 2001] and large bolls from the base leaving posterior half portion of the body outside the bolls [Munro, 1987]. This may cause abnormal nonreproductive growth [Bohmfalk et al., 2001]. In Egyptian cotton fields, $P$. gossypiella and $E$. insulana cause the greatest part of cotton yield losses (Amin et al., 2001). The larvae of $E$. insulana attack soft and growing tissues especially terminal bud of main stem, flower buds and bolls [Munro, 1987], which ultimately shed [Atwal, 1994]. 
Cotton bollworms are characterized by their high mobility and fecundity and have great capacity to develop resistance to synthetic insecticides used in their management (Kranthi, 1997). Due to high cost of protecting crops from these pests with chemical pesticides and the increasing resistance and resurgence to many chemical pesticides (Armes et al., 1992; Brewer \& Trumble, 1994), there is a growing interest in the use of biological products such as bacterial.

Those insects are attacked by numerous entomopathogenic bacteria such as Bacillus thuringiensis (Zidan et al., 1998; Sharma et al., 2001 and Aroonrat et al., 2003), B. cereus (Abul-Nasr et al., 1978 and Cheema \& Muzaffar, 1979), B. polymyxa (Abul-Nasr et al., 1978) and Streptococcus sp. (Narayanan et al., 1976 and Cheema \& Muzaffar, 1979). B. thuringiensis is active against many lepidopterous species and has no adverse effects on natural enemies of target pests (Fadare and Osisanya, 1998). A control program based on selective materials, which would allow survival of beneficial species and cause the mortality of destructive ones is desirable.

The search for new microbial agents for pest control is one of the most pressing needs in the field of biological control. Therefore, isolation of more local $B$. thuringiensis strains that would be more adapted to the local pest hosts and possesses greater insecticidal activities or broader host range (Abd-Elazim et al., 1991 and Osman, 1992) is required. So, isolation of the pathogens from the native ecosystem will help in successful biological control program (Keller, 1998).

The objective of this study aimed to collect, isolate and identify the local entomopathogeneic bacteria associated with cotton bollworms. In addition, the comparative efficacy of the local bacterial isolate and commercial bacterial biocides (Agerin) on cotton bollworms was evaluated under field conditions.

\section{MATERIALS AND METHODS}

\section{I- Samples collection and isolation:}

The present experiments were conducted at Aga district, in ElDakhlia Governorate throughout 2006 and 2007 cotton seasons. One feddan was assigned to collect, isolate and identify the local strains of entomopathgenic bacteria associated with the pink [Pectinophora gossypiella (Saund.)], spiny [Earias insulana (Boisd)] and American [Helicoverpa armigera (Hub.)] bollworm larvae on Giza 86, cotton cultivar.

Samples were collected weekly during 2006 and 2007 cotton season. Each sample consisted of 250 flower-buds (squares), flowers or bolls which were covered with polyethylene bag in the field and then picked up and transferred to the laboratory for examination.

To collect and isolate pathogeneic bacteria, living and dead $P$. gossypiella , $E$. insulana and $H$. armigera larvae showing primary infection symptoms were collected and put into sterilized tubes throughout the two studied seasons. The tubes were transferred to Microbiology lab, (Microbiology Department, Faculty of Agriculture, Mansoura University) to isolate and identify the bacterial species appearing on the larvae. 
The dilution plate method was used for the isolation of the insect microorganisms. The larvae was crushed, then sterile water was added. The suspension was shaked well for $10 \mathrm{~min}$, then diluted to the desired final dilution. One $\mathrm{ml}$ of the desired dilution was transferred aseptically into a series of Petri-dishes. Nutrient agar medium $(15-20 \mathrm{ml})$ was used as a bacterial nutrition medium. After incubation at $30 \pm 1^{\circ} \mathrm{C}$ for 3.5 days, plates were examined and the developed colonies were identified according to Holt et al. (1974).

\section{II- Pathogenicity of bacterial isolates:}

Insect sources : The pink and spiny bollworms were obtained from a colony maintained in the Integrated Pest Management (IPM) laboratory; Bollworms Department, Plant Protection Research Institute. Larvae were reared on a modified diet as described by Abd El-Hafez et al. (1982), while American bollworm larvae were collected from the previously mentioned experimental cotton field.

Preparation of inoculums : The bacterial growths on the nutrient agar slants were scraped, using $5 \mathrm{ml}$ sterile tap water, then transferred to a flask containing $50 \mathrm{ml}$ sterile nutrient broth. The resulting cell suspensions (1 $X 10^{6} \mathrm{cells} / \mathrm{ml}$.) were used for inoculation

To evaluate the pathogenicity of bacterial isolates on PBW, SPW and ABW larvae, each isolate was dispersed surfically on $5 \mathrm{gm}$ of the artificial medium and left until the diet absorbed the inoculum inside Petri-dishes containing the fourth instar larvae of PBW, SPW and ABW (about 20 larvae/Petri-dish). In each treatment, 0.025 Tween 40 was used. Each bacterial inoculum was replicated five times against each of PBW, SPW and ABW.

After 7 days of treatment, the treated Petri-dishes were examined and the percentage of pathogenicity was estimated. Reisolation for the pathogens has been carried out from the infected PBW ,SPW and ABW individuals.

III - Evaluation the comparative efficacy of local and commercial (Agerin) isolates of $B$. thuringiensis on cotton bollworms:

To report the comparative efficacy of the local isolate of bacterial pathogen ( $B$. thuringiensis strain I) and the commercial bacterial biocides (Agerin) on cotton bollworms an area of about $500 \mathrm{~m}^{2}$ was divided into three plots for planting Giza 86, cotton cultivar on the $2^{\text {nd }}$ of April ,2006 and16 th March 2007. In each treatment 0.025 tween 40 was used.

The first plot was treated with bacterial suspension $\left(1 \times 10^{6} \mathrm{cells} / \mathrm{ml}\right.$. of the local isolate of $B$. thuringiensis, strain I).The second plot was treated with the recommended dose of Agerin $6.5 \%$ (BT) $32000 \mathrm{IU} / \mathrm{mg}$. In the first season, the cotton plants were sprayed with bacterial suspension of the local isolate and Agerin on the $27^{\text {th }}$ of July and $24^{\text {th }}$ August. While, in the second season the local isolate and Asgerin were applied on $24^{\text {th }}$ of July and $28^{\text {th }}$ of August 2007. The third experimental plot (as control) was left without treatments. All experimental plots received regular cultural practices and no insecticides were used during flowring and fruting stage against bollworms.

Sampling program: To evaluate the efficiency of local isolate and Agerin against pink, spiny and American bollworms compared to the control 
treatment, samples of green bolls or flower buds were collected weekly and examined and the infestation percentages with each cotton bollworm species were estimated as follows:

$$
\text { Infestation \% }=\frac{\text { No. of infested bud or bolls }}{\text { Total No. of collected sample }} \times 100
$$

Each sample consists of 100 bolls from each plot.

\section{RESULTS AND DISCUSSION}

\section{Isolation and identification of entomopathogenic bacteria:}

Three strains of entomopathogenic bacteria (strain I, II and III) belonging to Bacillus thurengeinsis were isolated from the pink (PBW) $(P$. gossypiella), spiny (SBW) (E. insulana) and American (ABW) (H. armigera) bollworms. In addition, two bacterial pathogens namely, Streptomyces avermecti and Micrococcus sp. were isolated from bollworm larvae.

\section{Pathogenicity of bacterial isolates to PBW, SBW and $A B W$ larvae:}

The pathogenicity of each pathogen suspension was evaluated under laboratory conditions against the fourth larval instar of PBW. As shown in Table (1), the percentages of infection caused by B. thurigiensis (strain I, II and III), S. avermecti and Micrococcus sp. induced (95.2 $\pm 5.8,80.4 \pm 7.9$ and $82.0 \pm 10.1 \%), 78.8 \pm 12.1$ and $66.2 \pm 7.9$ infection percentages, respectively, while the control experiment (distilled water) had $1.0 \pm 2.2 \%$.

Table (1): Pathogenety of isolated bacteria, Bacillus thuringeinsis (strain I, II, III), Streptomyces avermecti and Micrococcus sp. to the fourth instar larvae of Pectinophora gossypiella [L.S.D value $=9.04(P=5 \%)$ ].

\begin{tabular}{|l|l|}
\hline \multicolumn{1}{|c|}{ Pathogen } & Infection\% \\
\hline B.thuringeinsis & \\
$\quad$ Strain I & $95.2 \pm 5.8$ a \\
Strain II & $80.4 \pm 7.9 \quad$ b \\
Strain III & $82.0 \pm 10.1$ b \\
S.avermecti & $78.8 \pm 12.1$ b \\
Micrococcus sp & $66.2 \pm 7.9 \quad$ c \\
\hline (control) & $1.0 \pm 2.2 \quad$ d \\
\hline
\end{tabular}

Statistical analysis revaled that $B$. thurigiensis strain I resulted in the highest pathogenicity to PBW, while $S$. avermecti and $B$. thurigiensis (strain II and III) ranked second in the order of activity. Micrococcus sp. Induced the lowest pathogenicity .

In respect to SBW larvae the pathogenicity of bacterial isolates to the fourth larval instar of SBW under laboratory conditions showed that there are significant differences for bacterial infection between the inoculated and control larvae. The percentages of infection caused by $B$. thurigiensis (strain I, II and III), S. avermecti. and Micrococcus sp. were (100 $\pm 0.0,87.2 \pm 7.8$ 
and $81.0 \pm 4.5 \%), 73.4 \pm 6.9$ and $74.6 \pm 11.4 \%$, respectively, while the control experiment (distilled water) had no infection.

Statistical analysis indicated that $B$. thurigiensis had the highest pathogenicity to SBW(Table2). While, the percentages of infection caused by. S. avermecti. and Micrococcus sp. ranked second in the order of activity with no significant differences between them.

Table (2). Pathogenety of isolatal bacteria, Bacillus.thuringeinsis (strain I, II, III), Streptomyce avermecti and Micrococcus sp. to the fourth instar larvae of Earias insulana. [L.S.D value $=6.77(P$ $=5 \%)$.

\begin{tabular}{|l|c|}
\hline \multicolumn{1}{|c|}{ Pathogen } & In fection\% \\
\hline B.thuringeinsis & $100 \pm 0.0 \mathrm{a}$ \\
$\quad$ Strain I & $87.2 \pm 7.8 \mathrm{~b}$ \\
Strain II & $81.0 \pm 4.5 \mathrm{~b}$ \\
Strain III & $73.4 \pm 6.9 \mathrm{bc}$ \\
S.avermecti & $74.6 \pm 11.4 \mathrm{bc}$ \\
Micrococcus sp & $0.0 \pm 0.0 \mathrm{c}$ \\
\hline (control) & \\
\hline
\end{tabular}

The pathogenicity of each pathogen suspension was evaluated under laboratory conditions against the fourth larval instar of ABW(Table3). The obtained results indicated that there are significant differences were apparent for bacterial infection between the inoculated and control larvae. The percentages of infection caused by $B$. thurigiensis strain I, II and III), Streptomyces avermecti. and Micrococcus sp. (90.0 $\pm 6.8,78.6 \pm 5.5$ and $80.0 \pm 6.8 \%$ ), $76.8 \pm 7.2$ and $60.0 \pm 8.6$ infection percentages, respectively, while the control experiment (distilled water) had no infection.

Table (3). Pathogenety of isolated bacteria, Bacillus thuringeinsis (strain I, II, III), Streptomyce.avermecti and Micrococcus sp. to the fourth instar larvae of Helicovepa armigera [L.S.D value $=$ $7.07(P=5 \%)]$.

\begin{tabular}{|l|l|}
\hline \multicolumn{1}{|c|}{ Pathogen } & In fection\% \\
\hline B.thuringeinsis & \\
$\quad$ Strain I & $90.0 \pm 6.8 \mathrm{a}$ \\
Strain II & $78.6 \pm 5.5 \mathrm{~b}$ \\
Strain III & $80.0 \pm 6.8 \mathrm{~b}$ \\
S.avermecti & $76.8 \pm 7.2 \mathrm{~b}$ \\
Micrococcus sp & $60.0 \pm 8.6 \mathrm{c}$ \\
\hline (control) & $0.0 \pm 0.0 \mathrm{~d}$ \\
\hline
\end{tabular}

Statistical analysis indicated that $B$. thurigiensis had the highest pathogenicity to ABW, while B.thuringeinsis (strain I, II, III) and S. avermecti ranked second in the order of activity. Micrococcus sp. were the lowest entomopathogenic bacterium (Table 3). 
Abd El-Kareim, A. I. et al.

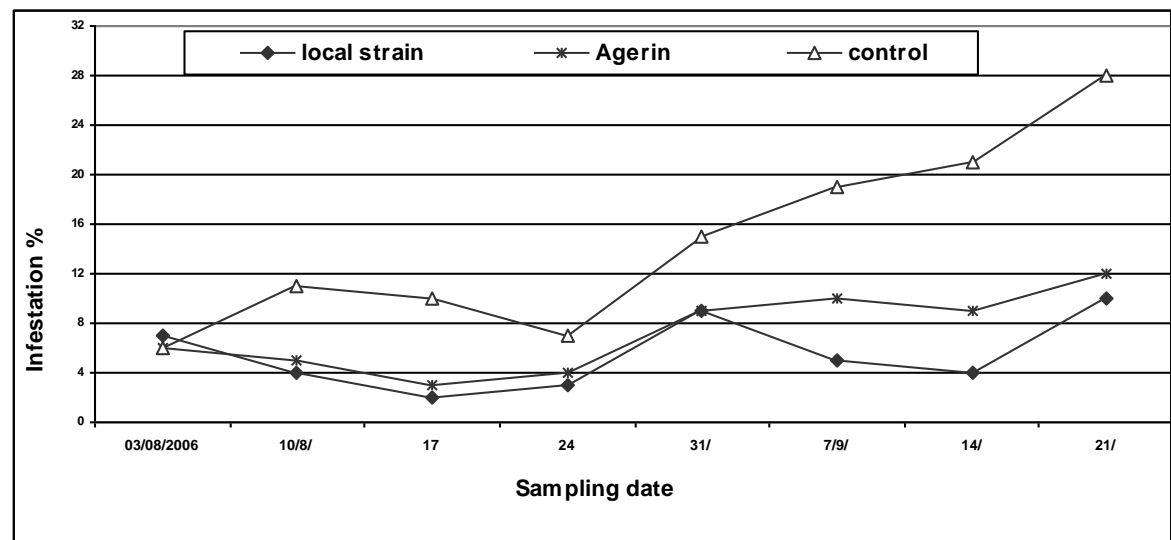

(A)

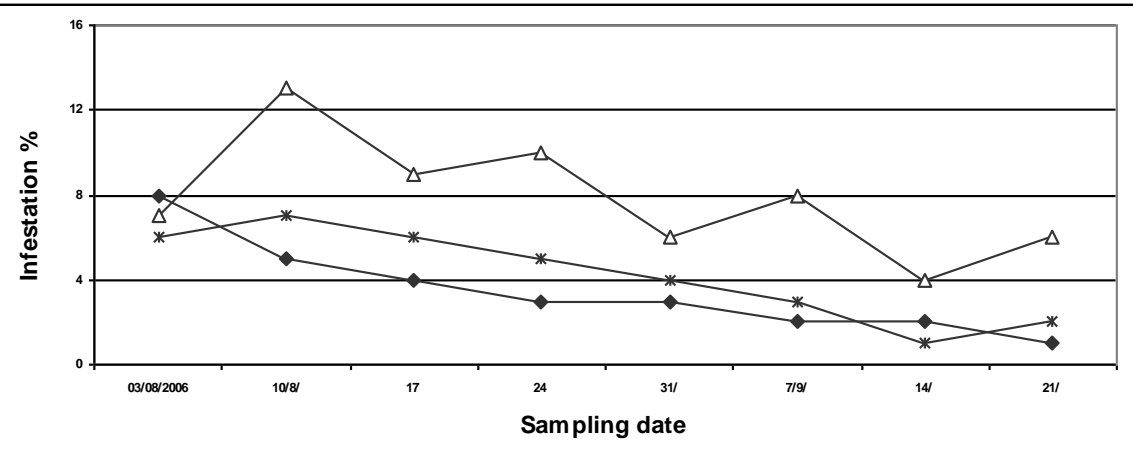

(B)

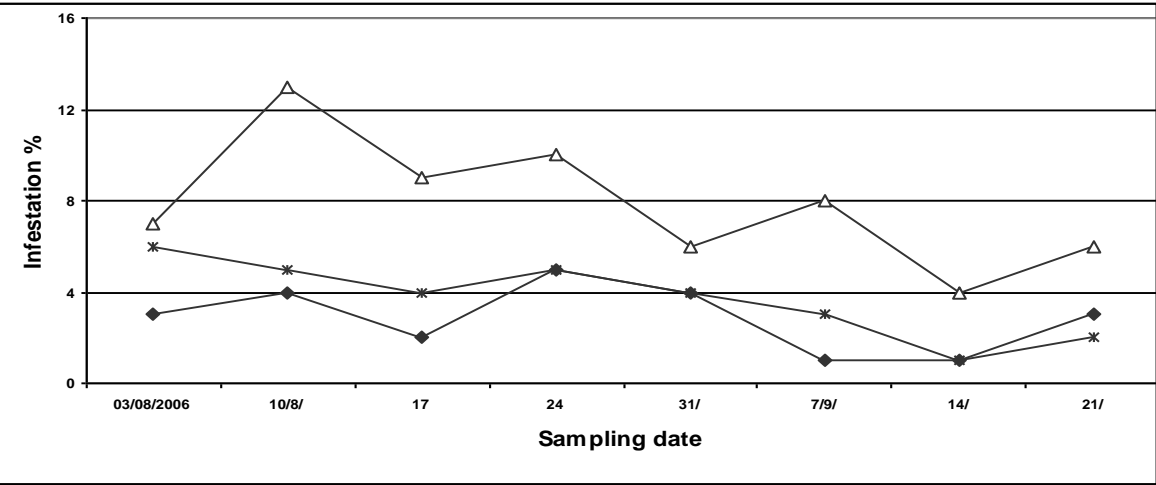

(C)

Figure (1). Weekly infestation percentages caused by $P$. gossypiella (A), E. insulana (B) and $H$. armigera (C) in cotton plots treated with local isolate of Bacilus thuringiensis and Agerin treatments during 2006 seasons. 
J. Agric. Sci. Mansoura Univ., 34 (10), October, 2009

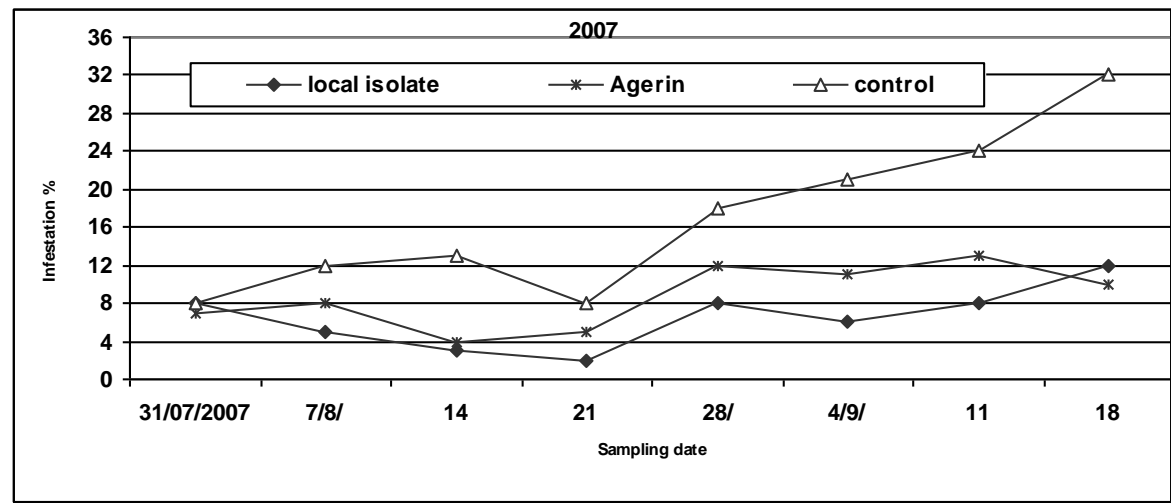

(A)

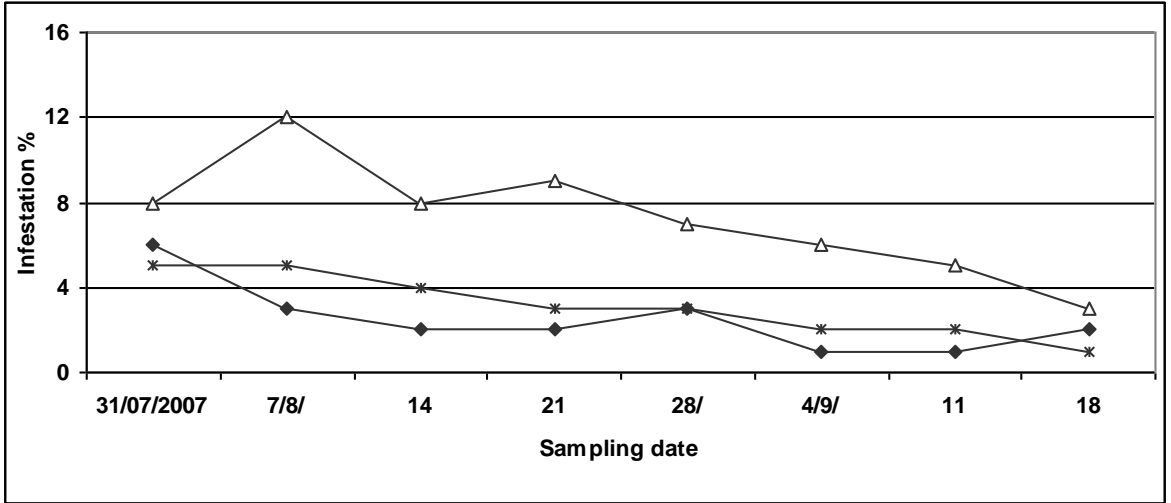

(B)

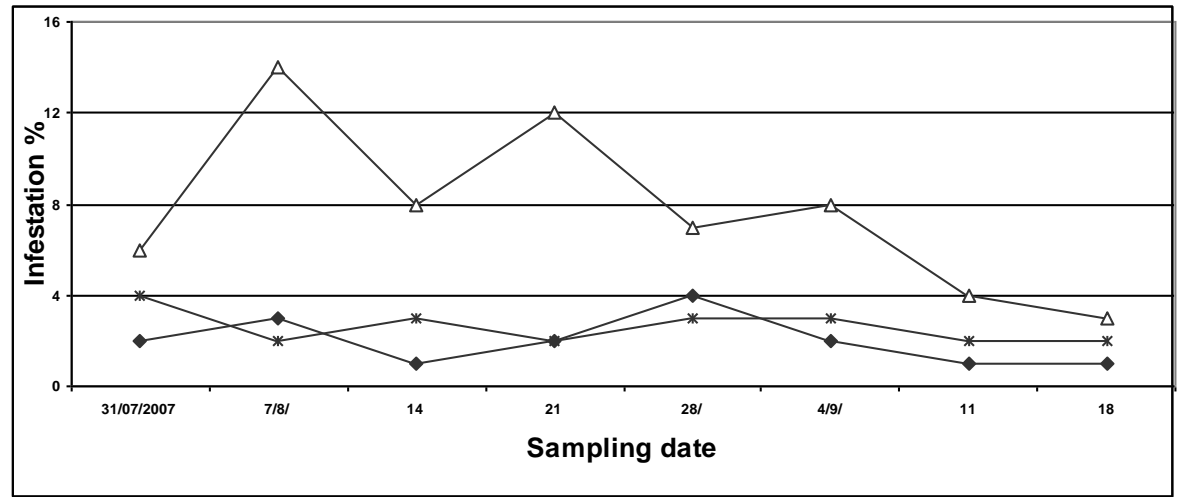

(c)

Figure (2). Weekly infestation percentages caused by $P$. gossypiella (A), $E$. insulana (B) and $H$. armigera (C) in cotton plots treated with local isolate of Bacilus thuringiensis and Agerin treatments during 2007 seasons. 
3. Comparative efficacy of local and commercial (Agerin) isolates of $B$. thuringiensis on cotton bollworms:

The effectiveness of local isolate of $B$. thuringiensis strain I as compared with recommended commercial isolate(Agerin) was evaluated under field conditions against $P$. gossypiella, $E$. insulana and $H$. armigera during two successive cotton seasons. The obtained data are summarized and illustrated in Figures (1 and 2).

As shown in Figures 1 and 2 the infestation percentages with all cotton bollworms ( $P$. gossypiella, $E$. insulana and $H$. armigera) were low in treated field with the local isolate of $B$. thuringiensis strain I in comparison with those in Agerin and untreated field during seasons 2006 (Figure, 1) and 2007(Figure, 2).

On the other hand,the obtained results indicated that in the first season (2006) the mean reduction percentages of infestation caused by PBW , SBW and ABW were $61.8,65.5$ and $74.2 \%$ in cotton fields treated with the local isolate of $B$. thurengeinsis strain I(figure 3 ). While, the mean redaction percentages of infestation in Agerin treatment were 48. 5, 56.9 and $66.1 \%$, respectively in comparison with control. In the second season (2007) the mean reduction percentages of infestation were 60.4, 55.6 \& $63.5 \%$ (for local isolate of $B$. thurigiensis) and 47.7, 46.0 and $52.4 \%$ (for Agerin treatment), respectively.
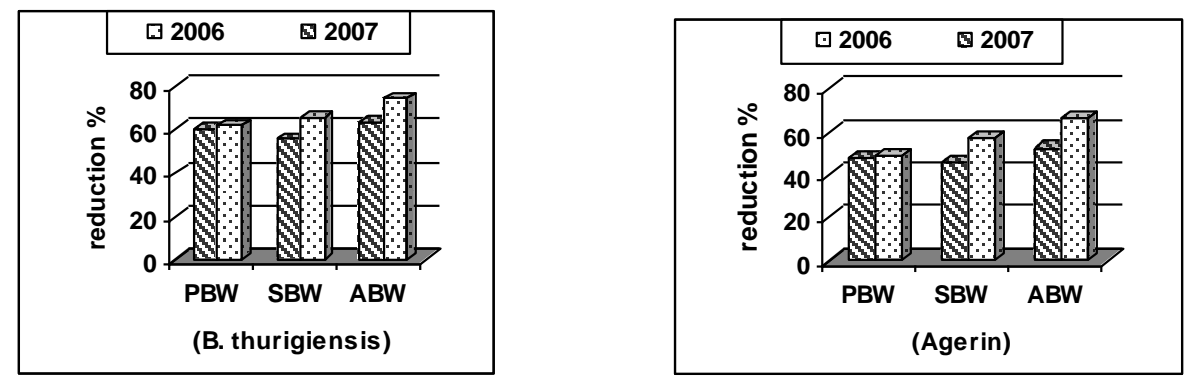

Figure (3) :The mean redaction percentage of infestation caused by pink (PBW), spiny (SBW) and American (ABW) bollworms in cotton field treated with $B$. thurengeinsis strain I and Agerin in comparison with control field during 2006 and 2007 seasons.

\section{DISCUSSION}

During the course of this study, three strains of entomopathogenic bacteria(strain I, II and III) belonging to Bacillus thurengeinsis were isolated from the pink ( $P$. gossypiella), spiny ( $E$. insulana) and American bollworms $(H$. armigera. In addition, two bacterial pathogens (Striptomyces avermecti and Micrococcus sp.) were isolated from the bollworm larvae. Also, $B$. thringiensis, S. avermecti and Micrococcus sp. were isolated from cotton bollworm larvae ( Abul-Nasr et al., 1979 , Bekheit et al., 1995 and El-Barbary, 2006). 
Laboratory experiments indicated that pathogenic bacteria, $B$. thurigiensis especially strain I had the highest pathogenicity to the pink, spiny and American bollworms, while $S$. avermecti ranked second in the order of activity. Micrococcus sp. exhibited the lowest pathogenicity to the tested larvae. Similar results were obtained by El-Barbary (2006). He mentioned that $B$. thurengeinsis exhibited the highest pathogenecity to pink and spiny bollworms in comparison with $S$. avermecti and Micrococcus sp.. Also, Abdel-Mageed (2005) recorded that $B$. thurigiensis was the most effective entomopathogen on seychellarum mealybugs followed by Micrococcus sp. and S. avermecti.

According to El-Hamady (1997), B. thuringensis is the most widely exploited pathogen, as its activity is attributed to endotoxin contained in the para sporal body (crystal). The mode of action of the tested bacterial species could be attributed to secretion of exochitinase activity when grown in a medium containing chitin. Allosamidin, a specific chitinase inhibitor secreted from certain $B$. thurengeinsis strains (Graham, 1998).

The effectiveness of the local isolate of $B$. thuringiensis (strain I) as compared with recommended commercial biocide (Agerin) a $B$. thuringiensis (strain I)gainst $P$. gossypiella , E. insulana and $H$. armigera was evaluated during two successive cotton seasons. The obtained data showed that Agerin had less efficiency for control the Pink, Spiny and American bollworms as compared with the local isolate, where the local isolate of $B$. thuringiensis (strain I) highly reduced infestation percentages with bollworms larvae in comparison with Agerin during the cotton seasons. Also, Abdel-Halim et al., 2002 reported that Agerin showed less efficiency against cotton bollworms. So, isolation of the pathogens from the native ecosystem can help in successful biological control program (Keller, 1998).

\section{REFERENCES}

Abd Elazim, M. F.; W. S. Abd Elaziz; M. A. Elsalam; M. A. Madkour and Y. A. Osman (1991). Isolation, molecular characterization and insecticide potentials of $B$. thuringiensis strains isolated from Egyptian soil. Am. Microbial. Abst. B-403, pp. 76.

Abd El-Hafez, A.; A. G. Metwally and M. R. A. Saleh (1982). Rearing pink bollworm, Pectinophora gossypiella (Saund.) (Lepidoptera-Gelechiidae) on kidney bean diet in Egypt. Res. Bull., Fac. Agric., Zagazig Univ., April, (576) $10 \mathrm{pp}$.

Abd El-Hafez; S. H. Taher and G. M. Moawad (1995). Potency of some new isolates of Bacillus thuringiensis against the pink and spiny bollworms. Ann. Agric. Sci., Fac. Agric., Ain Shams Univ., 40 (1): 411-416.

Abdel-Halim, A.; S. M. Soliman and H. A. Barrania (2002). Field evaluation of two biocides for bollworms control. Egypt. J. Appl. Sci., 17 (11): 279290.

Abdel-Mageed, S. A. M. (2005). Influence of certain natural enemies on some mealybug populations. M. Sc. Thesis, Fac. Agric., Mansoura Univ., 140 pp. 
Abul-Nasr, S. E.; M. F. S. Tawfik; E. D. Ammar and S. M. Farrag (1978). Occurrence and causes of mortality among active and resting larvae of Pectinophora gossypiella (Lepidoptera, Gelechiidae) in Giza, Egypt. Zeitschrift fur Angewandate Entomologie, 86 (4): 403-414.

Abul-Nasr, S. E.; E. D. Ammar; A. I. Merdan and S. M. Farrag (1979). Infectivity tests on Bacillus thurigiensis and B. cereus isolated from resting larvae of Pectinophora gossypiella (Lepidoptera, Gelechiidae). Z. Ang. Ent., 88 (1): 60-69.

Ahmad, Z. (1980). Incidence of major cotton pests and diseases in Pakistan with special reference to pest management, international consultation on cotton production. Research with focus on the Asian Region, Manila, Philippines, 17-21, November 1980, pp. 156-179.

Amin, A. A. A.; M. Gergis and M. El-Naggar (2001). Alternative infield refuge strategies for controlling certain cotton key pests in middle Egypt. The ESA 2001 Annual Meeting - December 2001 : An Entomological Odyssey of ESA, San Diego, CA.

Armes, N. J. , D. R. Jadhav, G.S. Bond and A. B. S. King 1992. Insecticide resistance in Hlicoverpa armigera in South India. Pestic. Sci., 34: $355-$ 364.

Aroonrat, T. A.; S. Manop and K. Uthl (2003). Preparation of spray-dried wettable powder formulations of Bacillus thuringiensis based biopesticides. J. Econ. Entomol., 96 (2): 292-299.

Atwal, A.S. (1994). "Pests of Cotton, Agriculture Pests of India and South East Asia", Kalyani Publishers, Delhi, pp. 281-294.

Bohmfalk, G.T., R.E. Frishie; W.L. Sterling; R.B. Mitzer and A.E. Knutson (2001). Identification, biology and sampling of cotton insects. Extension Bulletin B-933, The Texas Agricultural Extension Service, Texas A and M University System.

Brewer, M.J. and J.T. Trumble (1994). Beet-armyworm resistance to fenvalerate and methomyl-resistance variation and insecticide synergism, J. Agri. Entomol. 11, pp. 291-300.

Cheema, A. and N. Muzaffar (1979). Pathogens associated with the pink bollworm in Pakistan. Proc. Pakistan Academy of sciences, 1979 recd 1981. 16 (1): $43-44$.

EL-Barbary, M.M.M. (2006). The role of some natural enemies in the controlling of pink and spiny bollworms. M. Sc. Thesis, Fac. Agric., Mansoura Unvi. $136 \mathrm{Pp}$.

El-Hamady, S. E. E. (1997). Bioinsecticides-possibilities and limitations. 1st Nat. Conf. Appl. Using of Natural Enemies for controlling Insect and Mite pests. Mansoura, 4-5 March.

Fadare, T.A.; E.O. Osisanya (1998). Field evaluation of microbial insecticides on cotton bollworms and their natural enemies. Nig. Journ. Sci. 32: $72-$ 75

Graham, W. G. (1998). Involvement of chitenases from Bacillus thurengeinsis during pathogenesis in insects. Microbiology, 144: 2189-2194.

Holt, G. G.; N. R. Krieg; P. H. A. Sneath; J. T. Stanley and S. T. Williams (1974). Pergey's manual of determination bacteriology. 9th ed., Williams and Wilkins,a. 
Keller, S. K. (1998). Use of fungi for pest control in sustainable agriculture. In: Sustainable pest management: Safe use of new organisms in biological control. Phytoprotection, 79 (suppl.): 123-128.

Kranthi V. (1997). Insecticide resistance management strategies for central India. Central Institute of Cotton Research, Nagpur, India. Technical Bulletin.

Munro, J.M. (1987). "Tropical Agriculture”, Longman Scientific and Technical, New York, pp. 147-183.

Narayanan, K.; P. Thangavelu and T. R. Subramaniam (1976). New record of Bcillus cereus and Streptococcus sp. on the Pink bollworm of cotton, Pectinophora gossypiella (S.). Current Science, 45 (6): 235-236.

Osman, Y. A. (1992). Cloning of mosquito larvicidal toxin gene of $B$. sphaericus Neide. Egypt. J. Appl. Sci., 7 : 813-831.

Sharma, S. S.; H. D. Kaushik and V. K. Kalra (2001). Toxicity of Bacillus thuringiensis varieties Kurstaki and Aizawai against some lepidoptrous pests. Ann. Biology Hissar, June, 2001, 17 (1): 91-94.

Verma, D.K. (1999). "Applied Entomology", Mittal Publications, New Delhi, pp. 117-174.

Zidan, Z. H.; M. L. Abdel-Megeed; A. Abd El-Hafez; N. M. Hussein; H. M. ElGemeiy and M. M. Shalaby (1998). Toxicological and histological studies of Bacillus thurinigiensis, MVPII against larvae of Pink and Spiny bollworms. 7th Conf. Agric. Dev. Res., Fac. Ain Shams Univ., Cairo, December 15-17, 1998 Annals Agric. Sci., Sp. Issue 1, 319-332.

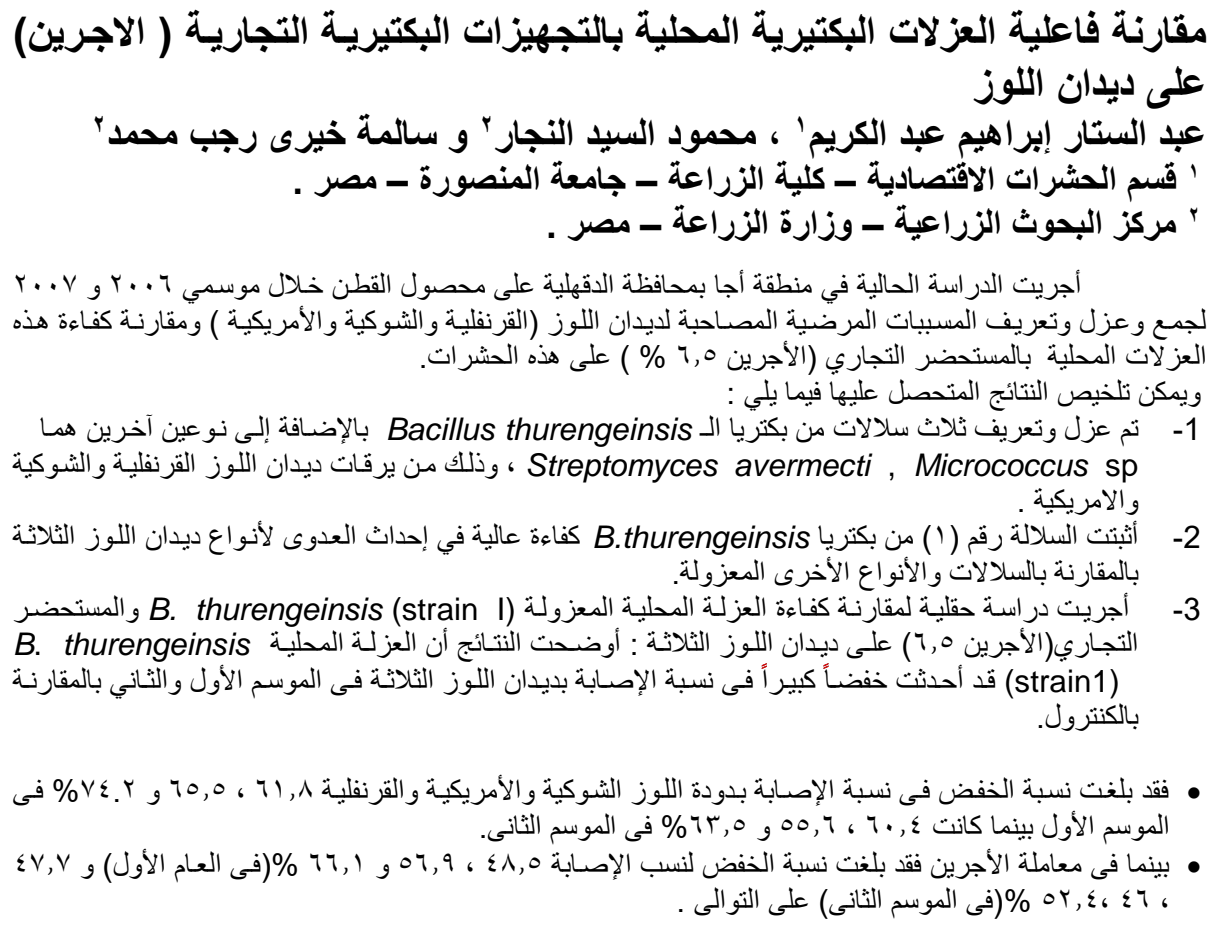


Abd El-Kareim, A. I. et al. 